\title{
TERRITORIAL SYSTEMS OF ECOLOGICAL STABILITY IN LAND CONSOLIDATION PROJECTS (EXAMPLE OF PROPOSAL FOR THE LSES OF KLASOV VILLAGE, SLOVAK REPUBLIC)
}

\author{
MILENA MOYZEOVÁ, PAVOL KENDERESSY
}

Institute of Landscape Ecology, Slovak Academy of Sciences, Štefánikova 3, 81499 Bratislava, Slovak Republic; e-mail: milena.moyzeová@savba.sk, pavol.kenderessy@savba.sk

\begin{abstract}
Moyzeová M., Kenderessy P.: Territorial systems of ecological stability in land consolidation projects (Example of proposal for the LSES of Klasov village, Slovak Republic). Ekológia (Bratislava), Vol. 34, No. 4, p. 356-370, 2015.

The observation of spatial and functional relations within ecosystems (Forman, Godron, 1993; Míchal, 1994; Jongman, 1995 a,b) and Territorial Systems of Ecological Stability and their design have a successful history not only in the Czech Republic, Germany, Austria, Hungary but also in Slovakia and other countries. The main principle of their design is to create an ecological network in intensively utilised landscape through revitalisation of the existing natural habitats and creation of new ones along with the proposal of their protection and management. The presented contribution represents an example of the proposed spatial framework of ecological stability and management measures in the cadastral area of Klasov. The cadastral area is characterised by prevailing large-block arable parcels and viticultural history. In spite of the agricultural character of the landscape, there are also areas with dispersed non-forest woody vegetation, preserved bank vegetation along streams, wetlands with reed associations, forest growths and mosaics of old abandoned orchards and vineyards as the potential elements of the proposed spatial framework of ecological stability. A functional LTSES framework and implementation of the system of ecostabilizing measures may contribute to increasing diversity of the territory and improvement of its spatial ecological stability. Efforts aimed at the recovery of vine-growing tradition represent a positive feature in terms of increased diversity in the territory.
\end{abstract}

Key words: ecological networks, stability, land consolidation, management measures.

\section{Introduction}

It was the Institute of Landscape Ecology SAS that developed the conception of the territorial system of ecological stability (TSES) in the Slovak Republic. In 1985, the Institute in cooperation with Urbion prepared the General Ecological Plan for the SSR and its integral part was the development of the TSES. The TSES conception contained the essential background for their creation, criteria for their selection, hierarchic levels and such. In 1992, the first conception of the General Plan of super-regional TSES (GNUSES) was developed for the territory of the SR. The GNÚSES is the basic framework of spatial ecological stability of the Slovak territory, spatial 
arrangement and relationships between ecologically most important and natural territories. In linkage to the European system of ecologically stable territories it is an important document for the protection strategy of ecological stability, biodiversity and the genetic resources of the SR. Following the General Plan, the national ecological network (NECONET) was prepared. It was based on the conception of building the European ecological network (EECONET), which applies delimitation of core areas and ecological corridors and territories for the development of natural elements of European and national significance. The main aim of the ECONET is the establishment of an integrated system of protected areas and potentially valuable territories in individual European countries following the international criteria and standards. Preparation of the TSES projects in Slovakia ran following the top-down principle starting from the GNUSES over the regional TSES and ending by the local TSES (Húsenicová et al., 1992). The mission of the regional TSES was to provide the conditions supporting conservation of the species diversity of the natural genetic resources of organisms in a particular region. The regional TSES represent the basic landscape-ecological source material for the preparation of the territorial and planning documentation by the Higher Administrative Units and for other branches and their documents (projects of land consolidation, forest economic plans, etc). Local TSES were prepared according to the regional TSES. The local level provides for the specific, and from the functional point of view, decisive conditions for conservation of the natural gene pool, and species diversity on local level. It builds upon the regional level and specifies it to the level of particular location of landscape elements. It is the basic landscape-ecological source for the preparation of territorial plans of communes, settlement zones and land-consolidating projects. At the beginning of the $21^{\text {st }}$ century, in Europe, there were at least 42 different active initiatives heading to the establishment of ecological networks; seven of them on the national level (Boitani, 2007; Buček, 2013). The Czechoslovak concept of the TSES (Buček et., 1986; Buček, Lacina, 1993; Maděra, 2010; Miklós, 2010; Pauditšová et al., 2007) according to Buček (2013) belongs to the longest applied methodologies utilised for the creation of ecological network. Meanwhile, the care for the ecological network undoubtedly complies with the requests of the European Landscape Convention, the aim of which is to conserve the landscape heritage and identity of cultural landscape (Buček, 2013). New trends in the area of building ecological networks emphasise the assessment and optimal use of services provided by individual types of ecosystems. Insufficient awareness of assets offered by ecosystems and their evaluation is also stressed in the aims of the EU for biodiversity (EC, 2008) and the new strategy for the protection of biodiversity until 2020. The need for land consolidation measures in Slovakia was urged by the critical situation in structure of property relationships, insufficient investments in agricultural facilities, the lack of the communication networks and ecological, water managing, soil protecting and landscaping measures. The implementation of land consolidation measures in Slovakia is defined by Act of the Slovak National Council No. 330/1991. The main aim of land consolidation is the legal and rational arrangement of the land and its utilisation and, at same time, securing its productivity according to the requirements and conditions of the environmental protection and TSES. The elaboration of land consolidation projects includes also preparation of the Local Territorial System of Ecological Stability (LTSES), according to which the ecological measures pursuing rationalisation of agricultural operations and provision of stability and aesthetic physiognomy of farming landscape are incorporated. The main aim of this 


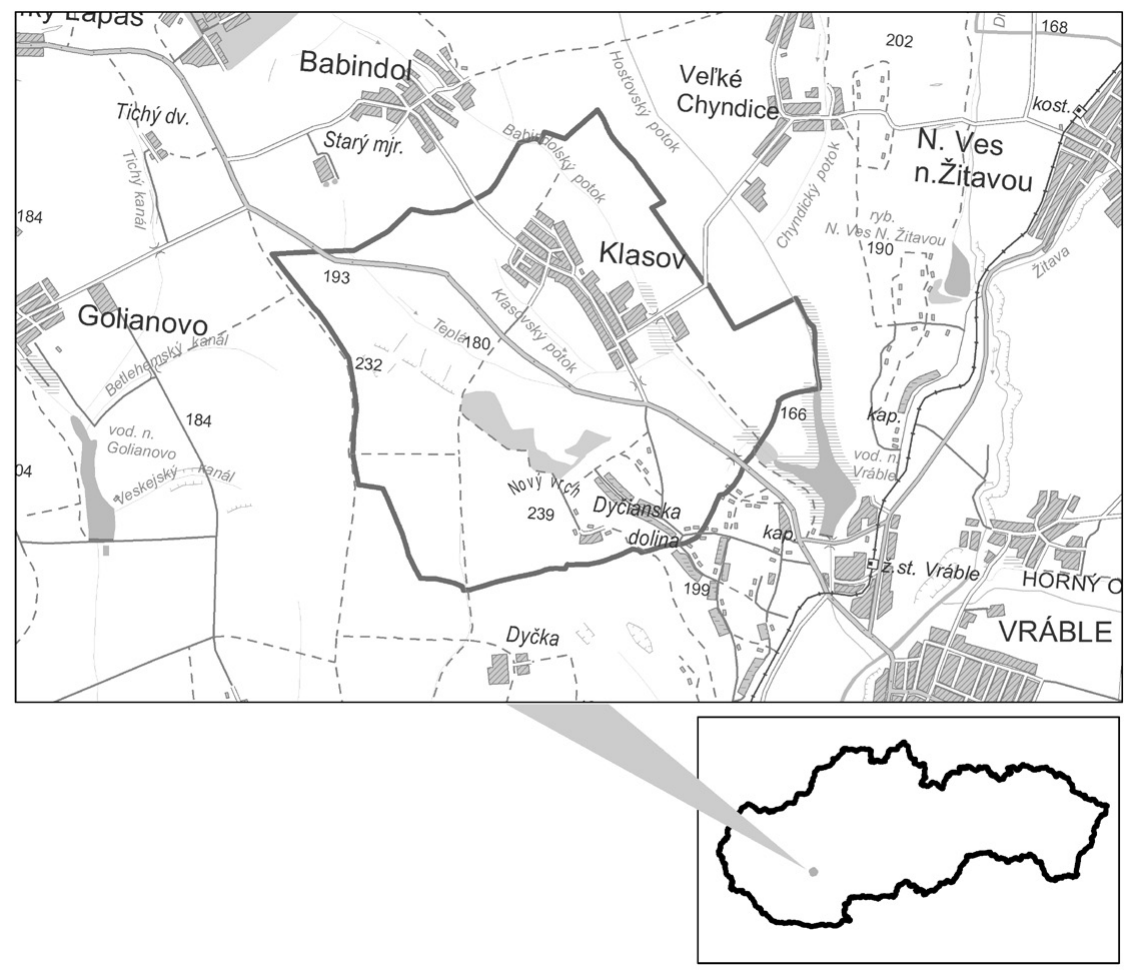

Fig. 1. Cadastral territory of Klasov village.

article is thus to demonstrate the process of LTSES elaboration for cadastral territory of Klasov village as an integral part of the land consolidation project funded by the EC. Klasov represents a typical agricultural settlement located in the Administrative Region of Nitra in the eastern part of the Nitra district, about $4 \mathrm{~km}$ north-west of the town Vráble and $13 \mathrm{~km}$ south-east of the Nitra (Fig. 1). The cadastral territory stretches in the central part of the Žitavská Hill Land in the valley of the Babindolský potok stream. Its hilly or slightly undulated relief built of the upper tertiary clay, sand, and gravel covered by loess is mostly deforested. The presence of the best quality soils, Chernozems and Cambisols, in the area predestined its exploitation for agricultural production. Klasov with its population of 1,206 people belongs to moderately big settlements with a balanced residential/agricultural function. The overall cadastral area is 1223.06 ha. Farmland dominates in landscape structure. Arable land (80\%) and the mosaic of narrow vineyards, orchards and gardens with structures related to vine cultivation (4.3\%) prevail in the farmland. Vine growing is a traditional activity in the village since the era of the Great Moravian Empire. The overall area of vineyards nowadays represents about 33 ha. The present trend of the gradual vineyards abandonment and disinterest in cultivation of this traditional crop, resulting to their gradual disappearance. Some typical buildings, particularly vine grower's 
houses with cellars, locally referred as hajnochy, still exist in this area. The cadastre of the village is characterised by low potential for nature protection. The prevailing part of the territory is under the first degree of protection. A single area located within the settlement, the Protected Area of Klasovský Park, is under the third degree of protection. However, there are elements located in the study area that are important from the landscape-ecological point of view that are not subject of legal protection, although they increase the ecological stability and biodiversity of the territory. They include a compact forest grows of Klasov, the patches of non-forest woody vegetation and wetland reed associations, bank vegetation of willow shrubs, mosaic of grapevine plants, permanent grasslands, fruit trees, and small blocks of arable land and such. In terms of LTSES, they represent potential biocentres, biocorridors, and interaction elements. Elements of the TSES on a higher hierarchic level are also important for the proposal of the LTSES framework. In Klasov area, they are represented by the regional biocentre, which is the Vráble Water Reservoir, and three regional biocorridors, including the Hostovský potok stream. Traces of anthropogenic activities, including the intensive agricultural production, which has changed the original geoecosystems and the overall character of the territory, are obvious in the rest of the territory. Accumulation of both the primary and secondary stress factors is highest in this part of the territory. Apart from agricultural areas, there are transport structures, dumping sites, pipeline networks and such. Secondary stress factors, which disrupt the environmental elements and their effects are negative in terms of the TSES, include air pollution, noise, pollution of surface and ground waters, chemical and physical soil degradation, susceptibility to land slides, radon risk, invasive species and such. However, these indicator values do not represent any noteworthy risk for the proposed LTSES.

\section{Methods}

The Methodological Guidelines of the LTSES design for the purpose of land consolidation issued by the Ministry of Agriculture of the SR in 2007 and rules for the preparation of the projects of local and regional TSES processed at the Institute of Landscape Ecology of the Slovak Academy of Sciences (Izakovičová et al., 2000), according to a decree of the Ministry of Environment SR No. 24/2003, which executes the Act of the National Council of the SR No. 543/2002 about nature and landscape protection were used for the proposal of the LTSES for the cadastral area of Klasov. The methodological procedure consisted of the following steps:

I. Analyses, represent design of the basic indicators of landscape properties indispensable for the LTSES proposal. Analyses consisted of following steps:

a) Analysis of abiotic components consisting of the analysis of relief, substrate-soil conditions, climatic and hydrological conditions in the given territory. The information about such properties is crucial for location of the new LTSES elements and from the point of view of proposed ecostabilizing measures in landscape.

b) Analysis of biotic components aims at mapping and basic characterisation of plant and animal species and their associations. The aim of this analysis is the quantitative and qualitative characteristic of fauna and flora. The quantitative characteristic involves the representation and distribution of biotic elements in landscape, while the qualitative characteristic considers the species composition, representation of associations and biotope types in landscape.

c) Analysis of the present landscape structure (PLS) reflects the impact of human activities on biotic and abiotic landscape elements and the degree of anthropogenic transformation of landscape. It also provides an idea about the present state of the biota and economic exploitation of the territory. PLS represents the material landscape elements with the particular spatial delineation. 
d) Analysis of socio-economic phenomena (SEP), it means phenomena that support or threaten the ecological stability of territory and consists of:

- analysis of the positive SEP, characteristics of the legal status of the territory concerning nature protection, natural, cultural and historical resources;

- analyses of the negative SEP, anthropogenic factors affecting the TSES elements that threaten or disrupt the natural development of ecosystems.

II. Syntheses The aim of syntheses in the framework of the LTSES represents the compilation of the following synthesised indicators:

a) Abiotic complexes, the result is the map of abiotic complexes, which displays the diversity of conditions for the individual life forms in the territory. It is based on combination of relief, geology, soil and climatic properties of the territory.

b) Representative geoecosystems, this synthesis reflects the potential diversity of ecosystems in the territory. It provides an overview of potential geoecosystems in individual geobotanical and geoecological landscape types as well as potential geoecosystems of regional character in phytogeographical or regional geomorphological geoecosystems or regional geomorphological units. Geoecosystems typology represents the basis for the selection of actual geoecosystems aimed at preserving the ecosystem biodiversity.

c) Synthesis of positive elements consists of delimitation of homogeneous areas with different combinations of socioeconomic phenomena concentrated on protection of nature, natural and cultural or historical resources and important landscape structures as the basis for identification of the real status of the LTSES.

d) Synthesis of stress factors (SF) aimed at creation of areas that reflect the type of SF and the rate of their negative effect. It consists of factors threatening individual elements of the LTSES.

III. Assessment and classification is based on the re-evaluation of the territory in terms of its biota (assessment of the status and biotope types diversity, species diversity, etc.), establishment of the ecological quality of PLS, assessment and classification of the territory based on positive and negative socio-economic phenomena followed by the delimitation of conflict areas from the landscape-ecological point of view. This part also contains the assessment of ecological stability by means of computation of the ecological stability coefficient (ESC).

IV. Proposals represent the final stage of the Project, consisting of the proposal of the framework of ecological stability on the one side and a series of management measures indispensable for the functioning system on the other. Among proposals, there is also one of eco-stabilising measures designed to increase the overall ecological stability of the territory.

\section{Results and discussion}

Proposal of the LTSES framework and eco-stabilising measures (Fig. 2).

Prior to the resulting proposal of the LTSES framework and proposal of eco-stabilising measures, it was necessary to asses the conflicts of stress factors whose effects are negative (threatening) in terms of landscape ecology with the positive (threatened) phenomena that provide for the ecological stability and preservation of species diversity in the cadastral area of Klasov. Result of such procedure is identification of landscape ecological problems that threaten and disrupt the stability, biodiversity, both the qualitative and quantitative properties of individual natural resources and population's living environment.

Based on spatial overlay of maps representing the positive and negative phenomena, three groups of landscape-ecological problems were identified:

1. landscape-ecological problems ensuing from the threat to the TSES elements, spatial 


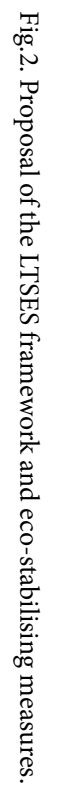
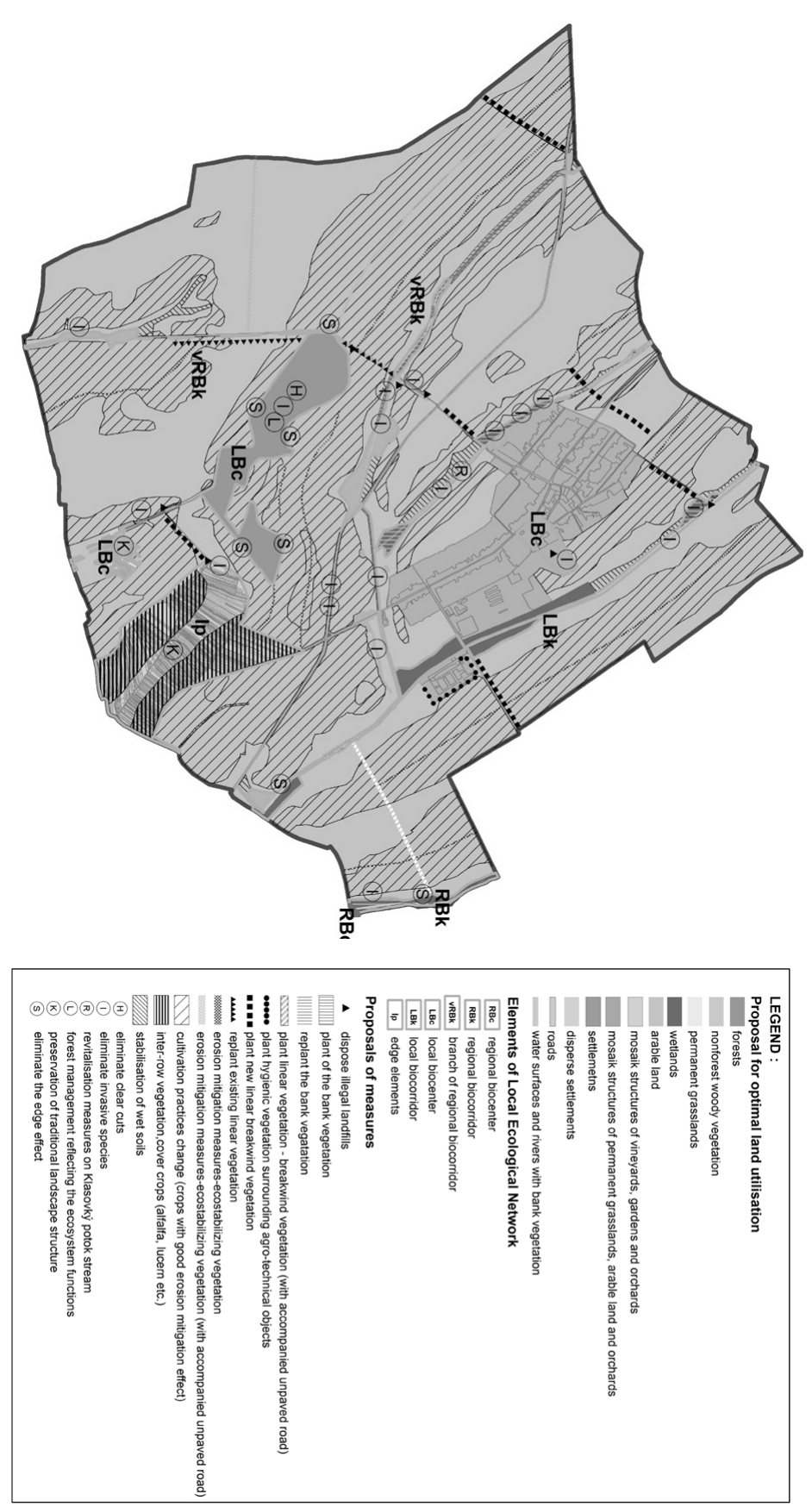
ecological stability and overall ecological quality of the territory;

2. landscape ecological problems ensuing from the threat to natural resources;

3. landscape ecological problems ensuing from the threat to humans and their living environment.

The territorial conflict of stress factors with the TSES elements considered ecologically stable, such as ecologically important segments or cultural and historical landscape structures, helped in identifying problems connected with the threat to the TSES elements, spatial stability and overall ecological quality of the territory. Such type of problems includes:

- $\quad$ potential threat of the regional biocorridor of the Hostovský potok stream and its bank vegetation by emissions of the surrounding sources of pollution;

- collision of road communication with the branch of the regional biocorridor of the Teplá stream;

- threat to the TSES element located in the vicinity of agricultural parcels due to intensive use of chemicals in farming;

- threat to the function of biocorridors raising from illegal landfills along the stream, silting of the stream by waste, risk of contamination by different substances and illegal release of domestic wastewater;

- threat to biotopes of national and European significance situated at the centre of the cadastre with local name Pri Potoku ensuing from using heavy agricultural machinery. Failure to respect the buffer zones leads to the destruction of the marginal parts of these biotopes;

- threat to biotopes of national and European significance due to the pollution of ground waters in localities situated at the centre of the cadastre in floodplains of brooks;

- threat to biotopes of European significance by low water level in summer months;

- risk of threat to biotopes of national and European significance by contaminated soils;

- destruction of bank vegetation by inappropriate management of the surrounding farming landscape, leading to synanthropisation followed by the diminishment of ecological importance of the given biotopes;

- threat to vineyards in the Dyčianska Valley due to erosion;

- decrease of ecological stability of forest growths in locality Klasovský Lesík due to the absence of buffer zones. The thin boundary between the intensively utilised land and forest stands leads to the destruction of vegetation in the contact zone;

- low level of ecological stability due to large-block arable fields and low proportion of ecostabilizing elements in the territory (non-forest woody vegetation);

- low diversity of plant and animal species as a consequence of monofunctional agricultural landscape with large blocks of arable fields;

- threat to biocorridors due to the disrupted hydrological regime (inappropriate regulation measures made in the past) especially during summer months with considerable water deficit which affects bank vegetation and subsequently the functionality of biocorridors;

- threat to biotopes of national and European significance and of bank growths due to the spread of invasive species like black locust (Robinia pseudoacacia), small flower touch-menot (Impatiens parviflora), Japanese knotweed (Fallopia japonica), staghorn sumach (Rhus typhina) etc.

- $\quad$ threat to the Protected Area of Klasovský Park due to illegal land filling; 
- inappropriate management of forest in Klasov, which is an important landscape-ecological element in intensively utilised farming landscape.

The basic problems connected with the threats to qualitative and quantitative properties of natural resources in the cadastral area are:

- disappearance of the traditional agricultural management forms such as vine growing, orchards, small-field tillage and such;

- decreasing water quality in local streams due to illegal release of domestic wastewater and leakage of landfills situated in the immediate vicinity of the streams;

- $\quad$ potential threat to quantitative and qualitative properties of soil resource due to water erosion, inappropriate management of agricultural land, that is, formation of large-block arable fields, removing the balks and remnants of non-forest woody patches and hedgerows, inappropriate crop rotation and such.

- potential threat to the best quality lands/soils ensuing from water erosion in localities Dyčianska Valley, Toved’ské Pole, southern part of Červený Majer, surrounding of streams Lúžtek, small enclaves in localities Slivkové and Pusté Jazero;

- $\quad$ threat to agro-ecosystems due to the spread of introduced invasive species;

- intensive agricultural production threatens the stream Hostovský potok, important local surface water source;

- $\quad$ risk of contamination of the best quality land due to illegal land filling;

- threat to soil and water resources represented by the transfer of industrial and transport exhalants from the surrounding industrial centres;

- the risk of threatening the qualitative indicators of ground waters by operation of car transport within the agricultural/industrial premises (possible fuel spill);

- threat to water and soil resources by negative effects of extreme precipitation events (flooding, acceleration of erosion process, etc.). Erosion is also responsible for the soil accumulation on the transport communications. The $1^{\text {st }}$ class road No. I/51, particularly the crossroads with the local road leading to vineyards, is especially threatened;

- the risk of threatening ground water resources and the best quality soils due to spillage of pollutants produced by mechanisms and chemical substances used in farming;

- high content of residual pesticides in soils as the residuals of excessive use of chemicals in the past.

- the risk of threat to soil due to heavy transport: exhalations, adverse effects of scavenging and such.

Problems related to threat to humans and their immediate living environment with the negative impact on population's health are:

- threat to environmental quality due to the transfer of dust from the surrounding fields, especially during dry and windy summer months;

- threat to the quality of housing due to landfills within the settlement (behind the elementary school on the premises of the abandoned distillery);

- impaired aesthetic quality due to electric poles and transformers situated right in the village;

- risk related to utilisation of polluted water for irrigation;

- increased risk of injury due to absenting pavements;

- risk of adverse impact of increased natural radon risk on population's health in the north- 
and south-eastern parts of the settlement area;

- risk of threat to population's health ensuing from cultivation of crops for direct consumption on soils with increased concentration of chemical substances;

- risk of threat to house gardens due to waterlogged soil, especially in the southern part of the settlement area next to Klasovský potok stream.

In spite the problems specified above, the study area belongs to those with small problems of local nature, which can be mostly eliminated by suitable ecological, environmental, technical or technological measures. Identification of these problems is the basis for the proposal of management measures necessary to reach sufficient ecological stability of the territory and functionality of the proposed LTSES elements.

The LTSES proposal for the Klasov territory is based on the delimitation of biocentres, biocorridors, and interacting elements. The selection of the LTSES elements was based on the landscapeecologically important components of the PLS, positive landscape elements and TSES elements of higher hierarchy (Regional TSES, Territorial Plan of the Supraregional System of Ecological Stability). The proposal of local territorial system of ecological stability for the Klasov according to (Moyzeová et al., 2007 - adapted) consists of the proposal of the TSES framework itself and the proposal of the management measures.

Five new LTSES elements as a follow-up to the elements of the TSES with the higher hierarchic significance have been proposed in the study area: One local urban biocentre located within the settlement i.e. LBC Klasovský Park, two local biocentres LBc Forest Growth of Klasov, LBc Mosaic of the Dyčianska Valley, one local biocorridor, that is, LBc Babindolský potok stream and one interacting element Ie Mosaic of Vineyards.

\section{LBc Klasovský Park}

The proposed urban biocentre represents the part of the settlement, which is now legally protected in the category of Protected Area. Its size is 3.99 ha while the southern part is a managed park area with the regularly mown lawn and dispersed trees. The prevailing wood species include, for instance, the small-leaved lime (Tilia cordata), large-leaved lime (Tilia platyphyllos), Norway maple (Acer platanoides), black locust (Robinia pseudoacacia), silver birch (Betula pendula), but also some conifers like yew (Taxus baccata), white cedar (Thuja occidentalis) and other. The age of growths ranges between 100 and 200 years. The park behind the sanatorium represents semi-natural forest with well-developed tree canopy and shrub layer. Main wood species are composed of (Fraxinus excelsior), common hornbeam (Carpinus betulus), and black locust ( $R$. pseudoacacia) while the shrub layer consists of field maple (Acer campestre), black elder (Sambucus nigra), dwarf elder (Sambucus ebulus), and other. The park vegetation is of high landscape and biological value providing biotopes for many animal species especially birds.

As this site has to function as the local biocentre, the following management measures should be implemented:

- all activities carried out in the territory must be in harmony with nature protection;

- invasive and ruderal associations in the northern part of the area such as the Japanese knotweed (Fallopia japonica) must be removed and overall cleaning and revitalisation of this neglected part must be accomplished; 
- $\quad$ health condition of wood species must be examined and damaged trees need to be revitalised.

\section{LBc Forest growth of Klasov}

The proposed biocentre consists of the black locust growths. In spite of the fact that black locust (Robinia pseudoacacia) belongs to invasive wood species, this solely compact area distinctly increases the ecological stability and biodiversity of the surrounding farming landscape. As clear cutting was applied here in the past, the proposed measures are:

- preparation of the new management plan in harmony with the function of the local biocentre;

- formation of a buffer zone around the local biocentres consisting of permanent grassland in combination with shrub and non-forest woodland. Provision for such management of the marginal parts of the forest, which will offer favourable conditions for the creation of the buffer zone, that is, more natural forest border. This measure will ensure the protection of forest against effects of intensive farming;

- application of edificatory and renewing interventions in an effort to produce mixed growths that are more stable and similar to the original vegetation;

- provision for the gradual transformation of the wood species composition into close to natural associations suitable for the existing habitat;

- avoid clear cutting method.

\section{LBc Mosaic of the Dyčianska Valley}

Dispersed settlement and mosaic of vineyards, permanent grasslands, abandoned orchards and non-forest woody vegetation form the other proposed local biocentres in the southern part of the cadastre, the Dyčianska Valley. These sites represent not only an important historical landscape structure but are also remarkable for their high biodiversity. They will contribute to the ecological stability of the surrounding farming landscape. In order to secure functionality of the biocentre, it is necessary to apply the following management measures:

- preserve the mosaic of the present structure with the extensive management of small-arable land blocks, permanent grasslands and orchards in order to avoid overgrowing (regular removal of self-seeded plants and mowing, etc.);

- $\quad$ eliminate ruderal associations and form a stable mosaic of landscape structure;

- control the management of small-block arable land and regulate the use of fertilisers in order to avoid soil and water pollution.

The biocentre network has been expanded by adding another biocorridor:

\section{LBc Babindolský Potok stream}

Along with the adjacent bank vegetation and reed associations in wetland and bank willow shrubs (biotopes of national significance), the LBc Babindolsky potok stream represents an important 
biotope for hares, pheasants, and other animal species. In order to function as a biocorridor, it is necessary to improve the vegetation continuity along the stream and implement additional management measures:

- avoid expansion of synanthropic, invasive, and expanding species into bank growths and wetland;

- $\quad$ preserve or improve the wetland regime in order to avoid its draining as these localities fulfil many ecological functions and increase the biodiversity of the territory;

- activities carried out in the vicinity of the stream must not threaten biotopes of national and European significance;

- if possible, create space for the expansion of growths up to the width of bank growths of 7 to $10 \mathrm{~m}$,

- activities carried out in the stream's vicinity must not threaten its function as local biocorridor; regulate the use of heavy machinery and the application of chemicals in farming; eliminate forceful or unjustified removal and pruning of trees and shrubs and so on.

\section{Ie Mosaic of vineyards}

The interaction element (Ie), represented by the mosaic of vineyards, permanent grasslands, vine-grower's huts (hajloky), and fruit trees also enhances the landscape-aesthetic value of the territory and the overall landscape diversity. This proposed interaction element naturally expands the local biocentre, the mosaic of the Dyčianska Valley. The proposed management of this territory should:

- maintain the mosaic of the present structure of vineyards, small-block fields and orchards as a significant cultural and historical structure of the territory;

- eliminate ruderal associations in order to establish a stable mosaic landscape structure;

- concentrate upon activities such as the management of small block arable land and the use of fertilisers in a way avoiding pollution of soil and water resources.

We have drafted proposals in order to increase the ecological stability of the territory based on the specified groups of landscape-ecological problems, measures protecting natural resources, proposals improving quality of the living environment and eliminating negative phenomena, including stress factors.

\section{Management and ecostabilizing measures protecting natural resources}

The following soil- water- and forest-protecting measures were proposed:

- cultivation practices reducing the risk of topmost soil layer loss,

- introduction of plots with ecological farming,

- comprehensive protection of arable land against erosion using an appropriate crop rotation applied to the best quality soil threatened by physical degradation processes.

Erosion mitigation measures must be applied according to Slovak Technical Standard (STN 75 $4501,2002)$, reflecting erosion mitigation crop rotation system in relation to slope inclination:

- cultivation of crops with good erosion mitigation effect (row crops such as cereals, oil rape, densely sown one-year crops such as fodders, flax, etc. on arable land with inclination from 


\section{3 to 12 degrees;}

- the inter-rows in vineyards, which are the most threatened by soil erosion (34.12 ha are threatened), should be grass seeded or alternatively covered by crops, with sufficient erosion mitigation effect (alfalfa, lucerne).

- planting protecting vegetation, erosion mitigation strips which slow down and retain the sheet runoff and thus protect the soil against water erosion;

- $\quad$ planting windbreaks reducing wind speed, temperature extremes, increase condensation and humidity of air and soil protecting the soil and population against adverse effects of wind and generally increase soil quality.

Other measures:

- $\quad$ stabilisation of waterlogged areas, soil unsuitable for farming or valleys where surface runoff accumulates;

- conditions of ecological farming; all conditions concerning the restricted amounts of organic and plant protecting means and the use of heavy machines posing the risk of fuel spill in case of farmland with high risk of threat for the ground waters must be strictly observed;

- division of large-block arable plots into smaller ones (50 ha) with a varied assortment of crops in order to create the mosaic-like landscape structures;

- introduction of preventive measures limiting the contamination of streams by communal wastes and illegal land filling through inspections and edification of population;

- avoid removing trees and shrubs on river banks (at a distance of $10 \mathrm{~m}$ from the bank line) in case of stream that is important in terms of water economy (Hostovský potok stream);

- conservation of forest growths as important ecostabilizing elements in the territory, development of suitable management of forest growth of Klasov, apply considerate management and ban large-scale felling in forest growths first of all in parts with high potential of water erosion;

- $\quad$ planting of game refuges, planting of non-forest woody vegetation as basic core elements for the renovation of representative geoecosystems, planting of wood species suitable for the given habitat;

- revival of traditional viticulture, restoration of the natural gene pool of fruit trees and expansion of orchards;

- $\quad$ optimise or adjust the species composition of wood growths, preferring the original species in terms of the habitant and eliminating the representation of other than autochthonous species to prevent their expansion;

- increase the share of natural restoration of forest growth, optimise ecological conditions in the herbaceous tier using the most considerate way of forest management by applying the methods of the selection forest and clearing of the herbaceous layer;

- as far as the protection of ground water and soil is concerned, it is necessary to respect the legal measures since the village has been classified into the A level of vulnerability.

- hygienic and buffer vegetation should be planted around roads in order to reduce the risk of transfer of foreign substances and exhalants to the surrounding farmland;

- it is desirable to carry out local monitoring focused on identification of foreign substance contents in soil and risk substance in the crops for the direct consumption in risk soils of the territory in question. 


\section{Environmental quality can be improved by the following measures:}

- increased frequency of revisions concerning the release of domestic wastewater into local streams, illegal land filling, construction of pavements, cleaning of local communications during rainy seasons and at the time of intensive field works, reclamation of the obsolete dwelling pool, adjustment of bank vegetation according to territorial plan of the village and revitalisation of the protected area of the Klasovský Park;

- measures limiting the spread of odours and noise from the local agricultural/industrial facility by planting the insulating strip of vegetation with an added architectural function using the wood species suitable for habitat and capable of enduring the adverse conditions attributable to operation of the facility;

- measures for revitalisation of vegetation along local streams within the area of the village by planting the accompanying vegetation respecting the spatial possibilities and architectural function of such vegetation;

- measures that will contribute to sustainable way of life in the concerned territory such as increased population's environmental awareness through edification;

- measures preserving the specific features of the village and its urban and architectural assets in accord with the proposals of the Plan for the Economic and Social Development of the commune;

- planting of a green strip with hygienic and protecting functions that should isolate the built-up area from the negative effects of agricultural production, especially dust;

- add accompanying vegetation along the local communications (restore the dirt roads in the cadastre and vegetation around them and game refuges, which disappeared due to the expanding farming and to restore roads leading to vineyards);

- $\quad$ indigenous fruit trees (walnut, plume, cherry and mulberry trees) should be preserved and not replaced by other introduced species;

- tradition of viticulture, traditional grapevine grower's huts with cellars and vineyards should be treated as valuable historical landscape structures (the Dyčianska Valley);

- $\quad$ stock-taking survey of wood species in the park next to the manor and legal protection for the oldest specimens.

- elimination of illegal land fills and establishment of a waste disposal premise/ repository,

- find solution for makeover and cleaning of the back part of the Park by removing the Japanese knotweed invasive species not suitable for the given territory.

\section{Effects of stress factors may be eliminated/mitigated by adopting the following measures:}

- $\quad$ it is necessary to add strips of fruit trees or non-forest wood vegetation as wind breaks along field roads or divide areas of large block fields into smaller units by non-forest wood vegetation and plant linear growths and game refuges that fulfil the ecostabilizing function in areas with the increased risk of water erosion and large-block system of use of arable land;

- removal of potential sources of contamination (illegal land fills in particular) for individual components of the environment and health hazard for population; 
- $\quad$ elimination of negative effects of stress factors on qualitative indicators of soil and water;

- apply the best available technologies for the gradual reduction of environmental contamination;

- $\quad$ avoid introduction of invasive species, which may reduce the species diversity of the territory by their aggressive conduct and to prefer autochthonous species for the given habitat.

\section{Conclusion}

According to the updated National Strategy for Protection of Biodiversity for the period 2012-2020 in the SR and in other countries, ecosystems and their services are degraded first of all due to landscape fragmentation. If the loss of biodiversity is to be stopped, it is necessary to conserve and strengthen ecosystem services and also renew the degraded ecosystems by means of inclusion of the ecological networks into documents such as territorial plans and Programmes of Economic and Social Development of Higher Administrative Units. In this way, it will be possible to contribute more efficiently to adaptation to climate change, to support the economic, territorial and social cohesion and to strengthen the protection of natural and cultural heritage. The establishment of the ecological networks will ensure advanced functional links between ecosystems in territories, which belong to the Nature 2000 system, between these territories and a wider landscape. TSES enjoys a different position in the Act 330/1991 about land consolidation, settling of land ownership, land offices, land pool, and land associations. It requires the processing of independent TSES documentation, which is used in different stages of the land consolidation project as a tool for preservation and introduction of landscape greenery and increased landscape-ecological stability. Processing of the TSES and their integration into the individual planning documents including the project of land consolidation is a contribution to the protection of landscape and landscaping itself including improvement of the living environment for humans. However, securing the functional framework of the TSES requires elaboration of the particular implementing projects (as a follow-up to the LTSES proposals), which will provide the transfer of proposals into reality. Land consolidation projects have recently become highly topical and they may represent a challenge and means to create appropriate conditions for the actual implementation of the TSES projects into everyday practice.

\section{Acknowledgements}

The contribution was prepared within the grant project of Ministry of Education of the Slovak Republic and the Slovak Academy of Sciences No. 2/0066/15.

\section{References}

Act No. 543/2002 on nature and landscape protection in wording of later issued provisions.

Act of the Slovak National Council No. 330/1991 on land consolidation, land property arrangements, land offices, land-pool and land associations in wording of later issued provisions.

Boitani, L., Falcucci, A., Maiorano, L. \& Rondinini C. (2007). Ecological networks as conceptual frameworks or operational tools in conservation. Conserv. Biol., 21(6), 1414-1422. DOI: 10.1111/j.1523-1739.2007.00828.x.

Buček, A., Lacina, J. \& Löw J. (1986). Territorial system of ecological stability in the landscape (in Czech). Životné Prostredie, 20(2), 82-86.

Buček, A. \& Lacina J. (1993). Territorial system of ecological stability (in Czech). Veronica, 8(1 special issue), 48.

Buček, A. (2013). Ecological network as natural infrastructure in the cultural landscape (in Czech). Životné Pros- 
tredie, $47(2), 82-85$.

Decree of the Ministry of Environment SR No. 24/2003 which executes the Act of the National Council of the SR No. $543 / 2002$ about nature and landscape protection.

Forman, T.T.F. \& Godron M. (1993). Landscape ecology (in Czech). Praha: Academia.

Húsenicová, J., Ružičková, J. et al. (1992). Methodology for projecting a regional and local territorial systems of ecological stability (in Slovak). Bratislava: URBION.

Izakovičová, Z. et al. (2000). Methodological guidelines for development of projects of regional and local TSES (in Slovak). Bratislava: Združenie Krajina 21.

Jongman, R.H.G. (1995a). Nature conservation planning in Europe: developing ecological networks. Landsc. Urban Plann., 32, 169-183. DOI: 10.1016/0169-2046(95)00197-O.

Jongman, R.H.G. (1995b). Ecological networks in Europe - congruent developments. Landschap, 3, $123-130$.

Maděra, P. (2010). Ecological networks in Czech Republic - current state and perspectives (in Czech). Životné Prostredie, 44(3), 121-123.

Miklós, L. et al. (1985). Ekologický generel ČSSR. Čast’ SSR. I. Etapa. Priestorová diferenciácia územia z ekologického hladiska. Záverečná správa P16-121-402/01. Bratislava: ÚEBE CBEV SAV.

Miklós, L. (2010). Networks in the landscape - territorial system of the ecological stability (in Slovak). Životné Prostredie, 44(3), 115-120.

Míchal, I. (1994). Ecological stability (in Czech). Brno: Veronica.

Moyzeová, M., Izakovičová, Z., Špulerová, J., Kenderessy, P. \& Lieskovský J. (2007). Local territorial system of ecological stability for the cadastral territory of Klasov for purposes of the land consolidation project. Bratislava: ÚKE SAV.

Pauditšová, E., Reháčková, T. \& Ružičková J. (2007). A methodology for local territorial system of ecological stability (in Slovak). Acta Environmentalistica Universitatis Comenianae, Bratislava, 15(2), 66-87. 